\title{
Using participatory research with student teachers in a South African English Education lecture-room: methodological implications
}

\section{Ansurie Pillay}

\begin{abstract}
This article focusses on the methodological implications of using participatory action research (PAR) in an English Education lecture-room at a South African university. It argues that research with, by and for student teachers may engender their empowerment and transformation. Using a system of interventions with literary texts as catalysts, the student teachers worked towards becoming agents of change in their future classrooms. Over a twoyear period, the student teachers and researcher worked collaboratively on the study that was framed by critical pedagogy. Information was collected using interviews, focus groups, student evaluations, drawings and written work and the data was analysed qualitatively. The study found that using PAR teaches student teachers important research skills that they may take into their classrooms. Further, the use of active dialogue and collaboration in a supportive environment facilitates PAR progressing successfully. Finally, critical reflexivity in PAR enables the process of change agency.
\end{abstract}

\section{Introduction}

This article focusses on the implications of using participatory action research (PAR) in an English Education lecture-room at a South African university. It argues that research with, by and for student teachers may engender their empowerment and transformation. Using a system of interventions with literary texts as catalysts, the student teachers worked towards becoming agents of change in their future classrooms. While the study generated many findings, this article focusses on answers to the following research question: What are the methodological implications of using PAR in a university lecture-room?

The study derives from two sources - the student teachers' anxieties about entering a seemingly dysfunctional educational system characterised by crisis 
(Bloch, 2009) and my concern that student teachers are not taught how to become agents of change and make a difference to their learners' lives through literature or otherwise. While Priestly, Edwards, Priestley and Miller (2012) conceptualise 'agents of change' as being reflexive, creative and committed to pursuing and embracing possibilities for change even in the face of obstacles, it is my contention that student teachers need to be developed and empowered to confront the challenges of the many South African realities, including the freedoms and challenges of a relatively new democratic political dispensation. I also believe that student teachers need to be equipped to redress inequalities still carried over by South Africa's past configurations of repression. Further, they should be taught to teach to make a difference to their learners' lives.

I entered the research process with the contention that if student teachers are empowered with sound disciplinary knowledge, effective pedagogical tools and an understanding of how to bring about academic and social change, then they can make a difference to the lives of their learners, irrespective of context or resources. I also understood that for the study to enable empowerment and transformation, the student teachers had to have a vested interest in the study and had to be co-researchers with me in determining the course of the study. If they were not empowered with a transformation agenda, it was possible that they would not recognise the forces that shaped and still shape them, and thus would reproduce the existing system. The way teachers define their roles and functions determines what is done in their classrooms. Ultimately, if teachers do not recognise that they have the power to exercise agency over who they are, how they teach and what they hope to achieve, then the cycle of disempowerment and failure will continue and society will replicate itself.

To enable agency, this study focussed on the literature component of English Education where student teachers are taught different literary texts and pedagogical tools to teach texts. While content and pedagogy appear to be taught, student teachers are not taught how to make a difference to learners' lives through literature, or how to use literature or any other means to address issues that confront learners and their communities on a daily basis. Thus, the power of literature to both transform and empower is often ignored. In the study, six literary texts, chosen prior to my being appointed to the university, served as catalysts for change. They were two novels, The Madonna of Excelsior by Zakes Mda (2002) and The God of Small Things by Arundhati Roy (1997); two plays, Sophiatown by The Junction Avenue Theatre 
Company (1988) and The Tempest by William Shakespeare (1623); and two films, The Colour of Paradise directed by Majid Majidi (1999) and Much Ado about Nothing directed by Kenneth Branagh (1993).

This article considers the methodological implications of using PAR to transform and empower student teachers to build their content knowledge and pedagogical skills and to develop agency. The article discusses the theoretical underpinnings of the study, and provides an overview of the PAR process and how it was used in this study. The article then engages with the methodological implications of using PAR in the study.

\section{The theoretical underpinning of the study}

The study was underpinned by critical pedagogy which is founded on the possibility of transformation, and has a critical nature and liberating function. This theory posits that education should be understood in its socio-historical and political context, and should commit itself to transformation towards democracy, justice, equality, and freedom. It focusses on human agency and possibilities for change (Biesta and Tedder, 2007). Critical pedagogy draws on Dewey's assertion that education can function either to create passive, risk-free citizens or a citizenry informed by a concern for justice and equality (Giroux, 2009). Building on Dewey's ideas, Freire (1970) insisted that teachers and students should be agents actively engaged in the process of constructing meaning together. For Freire, critical pedagogy should be used to highlight issues of democratic participation, agency, and voice (Darder, Baltodano and Torres, 2009), and, since this study was intrinsically concerned with democratic participation, agency, and voice, critical pedagogy was a clear choice with which to underpin the participatory action research.

\section{A brief overview of the participatory action research process and how we engaged with it in the study}

Participatory action research (PAR) emerged organically during the study, and, incidentally, was not named such until much later in the research process. For this study, student teachers and I used PAR, a form of action research, to enable social change. Our contention was that social change can begin with how teachers recognise and implement their roles and functions in the school 
system. This means that teachers have a responsibility to help learners grow and develop both academically and socially, and to enable learners to challenge and confront the stereotypes and constraints that have shaped their lives. Teachers thus have to have agency, serve as agents of change and empower learners to assume agency as well.

In a PAR study, change is possible through theory and knowledge-creation which emerges from dialogue between the participants and the researcher (Flood, 1998). PAR "is a means of putting research capabilities in the hands of the ... people so that they can transform their lives for themselves" (Park, 1993, p.1). It includes voices from groups not normally heard, credits community knowledge, modifies the role of the researcher to listener, works towards social justice, and necessitates recognising the power of and power relations between all participants. For this study, combining critical pedagogy with PAR was considered a sound decision in pursuing the aim of making research an agent of transformation (Swantz, 2008).

Hall (2005) suggests that the issue being studied in a PAR study should originate from the group. In this study, while the student teachers were not responsible for suggesting the idea for the research, they embraced wholeheartedly the idea of student teachers of literature becoming agents of change and recognised that it would be important for their future careers, professional identities and professionalism in their workplaces. They also recognised that the concepts of change and change agency were marginalised in their teacher education programme. In addition, they recognised their choices and responsibilities, and the power that they wielded in transforming themselves into agents of change. Thus, PAR was of immediate interest to them, as the outcomes of the research would affect them directly.

As is required of PAR, prior to the research process getting underway, the student teachers and I had to first reflect on and achieve a deep understanding of the historical, social, economic and political contexts from which the student teachers emerged, within which they study and the sociological realities of the schools where they will serve as teachers. Thereafter, we had to problematise the issue of how we could work together to use issues in the literary texts to serve as catalysts to enable them to become agents of change, and negotiate possible plans of action (Whitehead and McNiff, 2009). It was decided that with each text studied, various literary theories and pedagogical tools would be used and the concept 'agent of change' would be unpacked to move them closer to becoming agents of change. They would also consider 
how the literary texts could serve as examples of how texts could help learners grow and develop. It was decided that we would use interactive, cooperative learning strategies to achieve our objectives.

The process was thus a collaborative one involving a spiral of cycles of research, experiential learning and action (Boog, 2003) and spanned just over two years, which included four weeks of teaching practice and a visit to a sample of teachers three months into their serving as fully-fledged teachers. Each cycle of the PAR, which typically comprised three weeks of lectures and tutorials, involved an intervention designed by the group to ascertain the extent to which the aims of the study were being addressed, and at each cycle, the intervention was implemented, observed, reflected on and theorised before further action.

Interventions in the PAR process used the literary text as a springboard to focus on literary theories, issues under scrutiny (social justice issues, in the main), innovative pedagogical tools, and unpacking of the concept 'agent of change'. For example, when working with The Madonna of Excelsior, the literary theories, practical criticism (text-centred criticism with a close reading and analysis), reader response (the reader as an active meaning-maker), marxist literary theory (the economic forces, social hierarchies, individual struggles and larger class interests) and feminist literary theory (gender relations and gender representations) were used. By using various literary theories, we engaged more fully with the text and could read it from various perspectives, while still following critical pedagogy principles.

Each lecture was placed within a flexible framework and began with either a question or problem posed to the student teachers. The answers helped to reveal what they were thinking and the lecture then explored and built on the answers that emerged from the discussion. Within the lecture, specific issues that emerged from the text such as race, class, gender, culture, power and identity, among others, were discussed as a class or in pairs, and answers, in writing or orally, were shared with the class. Throughout the lecture, the student teachers' views were explored and challenged, issues were open to debate, they were encouraged to interrupt the lecture and ask questions, and, I asked questions, both convergent and open-ended.

Various activities were used in the lectures including short writing tasks, roleplays, problem-solving activities, and reading aloud, and various resources were drawn on including music, digital versatile disks (DVDs), pictures, film 
clips, newspaper articles, academic articles, interviews and critiques. At various times, language issues were pointed out incidentally with particular emphasis on the role of language as it constructed realities and social categories, and highlighted or suppressed agency, among other functions.

Another important aspect of the lectures was to unpack the concept 'agent of change' and determine how issues in the text could serve as catalysts for the student teachers to serve as agents of change. Initially, we unpacked the concept 'agent of change' and shared readings on the concept. Throughout the study, we attempted to understand a teacher's roles and functions in order to understand how to make a difference in the classroom and how to use issues in the text to enable learners' agency, participation, reflection and voice. Generally, the lecture format used various activities to address issues in the text, as pedagogical tools, and as ways to help them realise the aim of becoming agents of change.

After each PAR cycle, which included critical reflection of the cycle, qualitative data collection strategies (interviews, focus groups, student evaluations, drawings and written work) were used to evaluate the interventions and establish the extent to which the student teachers were moving towards becoming agents of change in their future classrooms. The data collected served to inform the next cycle and ultimately informed the conclusions drawn at the end of the study. A qualitative research approach provided opportunities for the student teachers to explore their experiences of the research process, and allowed for an in-depth understanding of findings. Thus, the flexible, fluid nature of qualitative research provided a perfect fit for PAR.

While the study worked with and collected some data from all student teachers in the English Education lecture-room, some data was collected from a purposeful sample. For example, the lecture-room observations, written work, drawings and student evaluations involved the sixty-six student teachers in the study. However, the focus groups, in cycles two and five, comprised eight student teachers, interviews were held with ten student teachers in cycles three and six, and teaching practice observations were carried out in seven classrooms after cycle five. In this study, a purposeful sample was chosen in terms of student teachers' race and gender because these two variables represented insights from various perspectives on the phenomena being investigated. 
The student teachers served as co-analysers, monitors and verifiers of the research process, and the data collection process provided many opportunities to corroborate and verify findings. While PAR does not aim to be objective and impartial, it does aim for an authentic, credible, rigorous research process. In this study, the spirals of cycles and action-positioned nature of the research ensured that data collection and interpretation coincided, and subsequent spirals of cycles were informed by the assessment and interpretations of data from previous cycles. Using an iterative process, the group had to refer back to and reflect on data collected previously. I worked collaboratively with groups of student teachers in the data analysis (different groups for different sets of data), and the groups identified recurring themes and patterns that emerged from the data. Further, as qualitative analysts, the groups had to be reflective about their own voices and points of view.

To ensure the validity of PAR, the suggestions made by Moser (1975) cited in Morrow and Torres (1995) were followed in this study. Firstly, the PAR process, functions and aims had to be transparent to the group. Secondly, there needed to be compatibility between the aims and methods used to achieve aims. Finally, I needed to ensure that I had an in-depth understanding of the situation and truthfully revealed all aspects of the research, including limitations, of which I had become aware.

Because of the recurring action and reflection, PAR is often viewed as a work in progress with many unanswered queries and unsolved debates (Reason and Bradbury, 2006). Ultimately, PAR confronts conventional, established social science research by re-aligning research that goes beyond reflective data produced by external authorities appraising variables to active moment-bymoment theorising, data gathering, and investigations arising in the midst of an evolving, developing structure (Torbert, 2004).

\section{Methodological implications of the study}

While there were many implications of the study, this article considers the four main methodological implications of using participatory action research (PAR) in this study. The first methodological implication of using PAR was that the student teachers were equipped to implement a PAR process, despite not being formally taught how to conduct the research. They experienced most aspects of the research process and their involvement in the various 
stages of the PAR cycles has enabled them to conduct research in their own classrooms. They co-designed the research plan that was required to identify problems, and collaboratively planned the interventions, implemented the actions, reflected on them and planned further. In their drawings, collected at the end of the study, they recognised the importance of 'interactive' and 'collaborative' research environments. They had a vested interest in the research process as they recognised that it responded to their needs and they demonstrated their willingness to be interviewed or to serve in the focus groups. I read this to imply a readiness to involve themselves in the research process that was designed to help them become agents of change. Further, despite data being anonymous and confidential, they were eager to reveal which responses from the data were theirs, even if the responses were unpopular ones and thus, were badly received by the others. I identified this finding as honesty on their part to reveal their current ways of thinking so that change may be implemented. When they understood that the study would be adapted in response to their direct needs, they accepted it as their own and ensured that their voices were heard. They embraced the control of the study, were empowered to shape its course, and recognised that issues of change have a strong chance of emerging through dialogue between the participants and the researcher (Flood, 1998). When interviewing four student teachers who had graduated and were working in their own classrooms, two of them referred to it as 'our study', indicating ownership of the process. A methodological implication of using PAR is that it put research capabilities in the hands of the student teachers so they could transform their lives for themselves (Park, 1993). This implication of using PAR was, for me, the most liberating aspect of the study as the student teachers' participation, involvement and control in the different cycles of the study enabled some form of empowerment and transformation.

The second methodological implication involved the limitations of the PAR process itself. I, rather than the student teachers, collected data and chose samples for data collection, for purely logistical reasons. While the student teachers planned the PAR cycles, co-analysed data and determined interventions, they were not involved in every step of the research process. Instead, they were informed about the processes involved in data collection and sampling. In retrospect, their involvement in data collection and sampling might have had an important effect on the findings. In addition, the group was aware that PAR involved ad hoc planning, not necessarily the norm in research studies. PAR as a research design has also been criticised for lacking 
specific methodological practices and a rigid framework (Waters-Adams, 2006; Van der Meulen, 2011), and the subjectivity of the group and the relationships that emanate from the various processes make PAR significantly different from traditional objective research. We thus had to make a concerted effort to work together as research partners, and responsibility for the research process was shared. We followed Moser's (1975) suggestions that the PAR process, functions and aims had to be transparent to the group and the aims and methods needed to be compatible (cited in Morrow and Torres, 1995). Throughout the study, we reflected upon the process as ethical issues emerged, negotiated, planned and implemented new cycles of research as carefully as possible, and theorised all findings to enable reliable access to practice.

The third methodological implication was the significance of using constant, active dialogue and engaged participation. The study was characterised by dialogue between the student teachers and me, and I tried to find nonthreatening ways to ensure comfortable participation for the group. During a focus group discussion in cycle three, the student teachers indicated that they were very comfortable talking in the English Education lecture-room with one saying, 'This is the only class I talk in'. Another pointed out, 'In other lectures, you just try to answer and sometimes, if it's wrong, people find it funny'. The comments indicated that the student teachers experienced a sense of trust and respect among the group. The lecture-room was thus perceived to be a safe, respectful place for them to participate and share their views. Thus, a nurturing, supportive environment may serve to enable voice and democratic participation. Moreover, such an environment may engender agency and enable possibilities for change (Biesta and Tedder, 2007; Giroux, 2009).

By the end of the study, drawings revealed that the student teachers believed that good teachers 'asked stimulating questions'; 'encouraged discussion'; set up 'debates to encourage higher order thinking'; and 'ensured that learners' views were respected'. In a final interview, a student teacher noted, that 'the questions, discussions and debates' were effective in 'making me understand things that you sometimes just accept'. The final reflection of the study indicated that the student teachers would 'remember to encourage talk and questions so learners learn how to examine issues' and 'remind learners that they have a voice and must use it. They must also respect other learners' thoughts', affirming the importance of creating space for learners' voices so that all learners are able to participate in an atmosphere of respect. Their 
comments revealed their recognition that dialogue and conscientisation are effective in a study and a classroom with a transformation agenda (Darder et al., 2009), and their views are supported by the findings of many researchers (Lowman, 1984; Golub, 1988; Bonwell and Eison, 1991).

A final and perhaps most important methodological implication involved the use of critical reflections at the end of each cycle to enable us to make informed decisions based on well-thought out ideas and help us move towards change agency. The critical reflections allowed for understandings and improvements of practices and ways of doing and being. A graduated student teacher interviewed after the study expressed her initial experiences of teaching as 'overwhelming', but she tried to 'keep a perspective on things ... reflect often ... know why I'm doing this', indicating her recognition of the benefits of critical reflection in her growth and development. It is hoped that the student teachers' abilities to contemplate and deliberate on actions, experiences and ideas gleaned from the study have prepared them for similar reflections in their own classrooms.

Not only did the reflections facilitate deliberations on our practices, it allowed us to question our own long-held views and those of others. For example, while the student teachers could recognise issues of social justice in the literary texts and could explain how they would engage learners on those issues, they often contradicted themselves in their discussions. For example, they would denounce sexism but would accept male behaviour 'because men behave that way'. Thus, while student teachers did not always agree with a literary character's actions, they accepted and understood them because he was a man. We therefore recognised the inconsistencies in how we judged texts and what we said in our personal capacities, and we had to challenge ourselves to confront stereotypes and biases. We recognised that we needed to be reflexive by engaging in explicit, self-aware analyses of how we influenced the findings of the study (Aasgaard, Borg and Karlsson, 2012).

For me as the researcher, the PAR process entailed daily reflections alone to assess the progress of the study. While I was the facilitator and researcher in the PAR study, I was also the student teachers' lecturer and assessor. While the roles of facilitator and researcher were shared with the student teachers, such that data analysis and verification, and critical reflection and planning for the next cycle were undertaken collaboratively, the roles of lecturer and assessor were not. I could therefore wield power within the research process and could arrive with biases related to the research process (Waters-Adams, 
2006). I had, therefore, to mediate the research process very carefully, to enable all the roles to function successfully.

To ameliorate power imbalances, I attempted to empower myself with knowledge about PAR and to actively enable inclusion and active involvement of the student teachers in the data analysis and data verification. Further, I made a conscious effort to ensure that the researcher-participant relationship was a dialogical one where both the student teachers and I contributed to the research process, to the knowledge generated, and to the evaluation of the process. But, I realised I needed to continue developing my self-knowledge by critically reflecting on my core values, multiple identities, locations of power and privilege, and how these understandings influence interactions with others and with research practices. I understood that my work experiences and interactions moulded my identity, influenced my practices and shaped my values. While I recognised my core values as supportive of my actions, I realised that I had to re-examine my values constantly as I worked through the research process. Constant, honest and mindful reflection was therefore necessary to manage the research process. To achieve the transformation of student teachers in the study, I needed to reassert my emancipatory intention and had to ensure that actions were in the best interests of the student teachers. To foreground the intention, ongoing action and reflection had to occur and extend beyond the PAR activity.

The critical reflections exposed a further methodological implication. We recognised that the research was a collective undertaking influenced by many forces within and beyond the academic institution. For example, there had to be an awareness that the student teachers and I work within our own institutional and community environments, which involve our own sets of values and structures of power. We therefore needed to examine power relationships in the research setting, including individual and institutional relationships. We recognised that we exist within wider social, political and economic structures that shape our experiences of race, gender, class, culture, sexual orientation and other aspects of identity.

We realised that the PAR study, in general, and critical reflections, in particular, had brought the group closer together and an ethos of trust, honesty and respect were evident. Since we worked as a collaborative group of investigators who were collectively responsible for the study, we had to establish a relationship that was based on open communication and commitment to bring about change. It is possible that the strategies used 
during the study, such as sharing of stories and role-plays, had created a bond between us. In their written work, the student teachers noted that the PAR process had allowed them to 'build relationships' and 'learn to respect each other's views', and I had to ensure that I respected them as active agents of change, mindful of the dynamics of relationships, including the issues of power and hierarchy playing out in the research situation (Johnson and Christensen, 2007).

In addition, the critical reflections enabled the group to be reflexive about their becoming teachers. In the focus group at the end of cycle two, two student teachers noted, 'This study has made me think about whether I can make a difference to the kids at school' and 'How do I become a change agent? You ask us that and I have to think about it. I have to think about becoming something'. The two student teachers identified that they thought about becoming change agents, thus, the possibility for change was highlighted.

During cycle five, a student teacher observed that during Teaching Practice she 'wanted to focus on the content and methods. But I couldn't help saying, how do I make a difference to their lives'. In the final focus group, a student teacher noted that 'the study makes me think ... who am I as a teacher in South Africa? Can I create my own identity? Can I break the mould?' Her comments reflected that she was thinking deeply about her role not just as teacher but as a teacher who wanted to make a difference. Her comments revealed that she was reflecting on her actions, experiences and thoughts, and was determined to forge her own identity. Another noted that, 'there is always some way to make a difference. I feel guilty if I let it pass' and yet another noted that she 'didn't want to dwell on change in learners' lives but once you are aware, you can't avoid it'. What the comments indicated is that they were becoming agents of change, whether they wanted it or not. They were aware that they could not avoid making a difference to their learners' lives. Further, they were changing and making a difference to their own lives. Freire (2009) points out that while teachers need a firm command of their subject matter and a thorough understanding of the curriculum, they also need to serve as agents of change by setting up opportunities for learners to engage with the subject critically. Freire's views are echoed by Fanon who points out that "what matters is not to know the world but to change it" $(2008, \mathrm{p} .13)$.

Finally, a student teacher pointed out that she would use issues that emerged from the literary texts to help learners develop academically and socially, but 
noted that she would 'use teaching moments from the texts, but I won't preach. They must make decisions, think hard, and apply it to their own lives and contexts. It must be theirs'. She continued, 'If I tell them . . . preach to them, I am, in a way, oppressing them'. While she knew that she was obliged to empower her learners and affirm their lives, she was equally aware that she had to reflect on her practices so that she did not impose her power and advantage on her learners. Overall, she recognised that her teaching of literature and the practices that she used had to be supported by well thoughtout philosophical and ideological underpinnings if she was to make a difference to her learners.

By the end of the study, anonymous student evaluations revealed that all the student teachers aspired to be agents of change and had a clear understanding of themselves as agents of change who need to have a clear vision of their roles and functions, ethical and democratic principles, and a commitment to improving their own and their learners' lives. They also understood the need for life-long learning and regular reflection on their professional identities. It is significant that one student teacher noted, in the anonymous evaluation, that $\mathrm{s} /$ he did not believe that $\mathrm{s} / \mathrm{he}$ would become an agent of change, but still believed that teachers needed to be agents of change in their classrooms, signifying an aspiration to an ideal. All others believed they would serve as agents of change and in an interview, a student teacher noted that she had 'a yardstick to use' and wanted to be 'a teacher who has some significance'. In their drawings, student teachers noted that an effective teacher 'had a passion for making a difference in learners' lives'; convinced learners 'to think out of the box'; and 'instigated change and influenced learners positively'.

Responses signified that they were committed to bring about change and able to reflect on their thoughts and actions (Priestley et al., 2012), were able to "live a critically conscious presence in the pedagogical process" (Freire 1970, p. 202), and could recognise their own agency and voice in the process of becoming agents of change in their classrooms so that learners became critical, active human beings (Giroux and McLaren, 1996).

Ultimately, critical reflection played a significant role in shaping who we became. While it is difficult to assess concepts of emancipation, agency, empowerment and democratic participation within the confines of the study, the student teachers did establish and understand, with clarity, what their goals, values, capacities, and functions are, and that represents an important starting point for them to take it further when in their own classrooms. I recognised growth and development in their ability to make choices, pose 
questions and reflect on their actions and words. The impact of the study on the participating student teachers' could be seen in their use of participatory, transformative discourse. At the end of the study, they were able to use, with confidence, the important concepts of the study. In their final reflection, they considered the importance of taking cognisance of Lortie's (1975) 'apprenticeship of observation', Freire's (1970) concepts of 'banking' and 'libertarian' education and other concepts such as 'agency', 'voice', 'hegemony', 'critical literacy', 'conscientisation', 'collaborative strategies' and 'humanising pedagogy'. While such concepts, and others, were engaged with through each cycle, they could use them independently and with a clear understanding of how the concepts worked in authentic, practical situations. However, I understood that while they were conversant with discourse, it remained to be seen if the ideas were transferred to real situations.

At the end of the sixth and final cycle, the group stepped out of the research process. However, the process of the student teachers becoming agents of change is a long-term one in their school environments. Four months into their first year of teaching, at the end of the first school term and during their first school break, four novice teachers, who were part of the study, were interviewed to determine whether the principles and ideas of the study were being transferred to their classrooms. A purposeful sample of novice teachers was chosen based on the race and gender of the teachers and on the material resources at their schools. The classrooms of the four novice teachers revealed varying learner numbers, ranging from twenty-five learners in materially advantaged schools where resources and facilities were of a very high calibre, to sixty learners in materially disadvantaged schools where there was a dearth of resources and facilities.

In their classrooms, all the novice teachers used largely learner-centred lessons to engage their learners. Of significance were their reasons for choosing strategies. They noted that the home language of many of their learners was not English, and that they chose strategies that would encouraged their learners to speak, practice the language, and hear the language being spoken or read. They also indicated that they questioned and challenged learners' ideas, and related the issues in the texts to learners' lives. Thus, they were using issues in the texts to help their learners grow and develop academically and socially.

All the novice teachers were clear about what they wanted for their learners. The first novice teacher noted that she "wanted to use the texts to expose 
learners to different cultures and social classes and to show them that people have similar needs and wants, despite outward differences'; another wanted his learners 'to succeed' and he let them know that he 'cared about them'; a third tried to help her learners 'with their problems, academic and social' and realised that she needed 'physical, mental and emotional strength to be a teacher'; and the fourth 'tried to motivate and encourage' her learners, who mostly 'wanted to improve their lot', and she noted that she 'could not abandon her learners and needed interventions'. The four novice teachers, while teaching in varied contexts and being aware of many different challenges, were committed to and aware of 'making a difference to their learners'.

Of the study, all believed that the study had been useful to them, noting that it had been 'vital' to their training, taught them 'how to cope', 'transformed their thinking', showed them 'how to reflect', gave them 'confidence', and 'empowered' them 'to make a difference' in their schools. When speaking about the study, one teacher believed that 'it was the only relevant, significant part' of his university degree.

While the four novice teachers seemed to be implementing a transformation agenda in various forms, the choices made by the others are not known. They left the research process empowered with some of the skills and capacities to continue the transformation of themselves and their learners, and they understood that they needed to continue to interrogate any unanswered questions and reflect critically on their doubts and uncertainties. McLaren (2009) reminds us that empowerment equips participants with the skills and courage to implement changes where necessary.

\section{Conclusion}

By using participatory action research (PAR) in this study, it became clear that research outcomes, action outcomes and critical reflection may be used to understand, confront and improve systems and practices, and may work together to provide practical solutions to issues of concern.

Ultimately, the use of PAR in this study taught the student teachers important research skills, and they left the study fairly well equipped to implement a PAR process themselves, recognising both the strengths and limitations of the research process. Further, they recognised the impact of using active dialogue, 
collaboration and participation in a nurturing, supportive environment to achieve aims. However, the most important implication of using PAR was that while they comprehended the strength of critical reflection to improve practices and understand the research process, they could discern the power of critical reflexivity to interrogate power imbalances and to shape their becoming agents of change in their classrooms. It became apparent that the use of PAR in a university lecture-room is not just feasible, its role as research of the students, by the students, for the students can prove very powerful in enabling empowerment and transformation.

\section{References}

Aasgaard, H.S., Borg, M. and Karlsson, B. 2012. Emancipation or symbolic participation: how can we 'do' action research as a democratic process? International Practice Development Journal, 2(1): pp.1-7.

Biesta, G.J.J. and Tedder, M. 2007. Agency and learning in the lifecourse: towards an ecological perspective. Studies in the Education of Adults, 39: pp.132-149.

Bloch, G. 2009. The Toxic Mix. Cape Town: Tafelberg.

Bonwell, C.C. and Eison, J.A. 1991. Active learning: creating excitement in the classroom: AEHE-ERIC Clearing House on Higher Education.

Washington: Jossey-Bass.

Boog, B.W.M. 2003. The emancipatory character of action research, its history and the present state of the art. Journal of Community and Applied Social Psychology, 13: pp.426-438.

Branagh, K. (Dir.) 1993. Much Ado About Nothing. DVD. UK: BBC Films.

Darder, A., Baltodano, M.P. and Torres, R.D. (Eds). 2009. The critical pedagogy reader $\left(2^{\text {nd }}\right.$ ed. $)$. New York: Routledge.

Fanon, F. 2008. Black skin, white masks. New York: Grove Press. 
Flood, R.L. 1998. Action research and the management and systems sciences. Systemic Practice and Action Research, 11: pp.79-101.

Freire, P. 1970. Pedagogy of the oppressed. New York: Seabury.

Freire, P. 2009. From pedagogy of the oppressed. In Darder, A., Baltodano, M.P. and Torres, R.D. (Eds), The critical pedagogy reader. New York: Routledge, pp.52-60.

Giroux, H.A. 2009. Teacher education and democratic schooling. In Darder, A., Baltodano, M.P. and Torres, R.D. (Eds), The critical pedagogy reader. New York: Routledge. pp.27-51.

Giroux, H. A. and McLaren, P. 1996. Teacher education and the politics of engagement: the case for democratic schooling. In Leistyna, P., Woodrum, A. and Sherblom, S.A. (Eds), Breaking free: the transformative power of critical pedagogy. Cambridge: Harvard Educational Review, pp.301-331.

Golub, J. 1988. Focus on collaborative learning. Urbana: National Council of Teachers of English.

Hall, B.L. 2005. In from the cold: reflections on participatory action research from 1970-2005. Convergence, 38(1): pp.5-24.

Johnson, B. and Christensen, L. 2007. Educational research: quantitative, qualitative, and mixed approaches ( $3^{\text {rd }}$ ed.). Los Angeles: Sage.

Lortie, D. 1975. School teacher: a sociological study. Chicago: The University of Chicago Press.

Lowman, J. 1984. Mastering the techniques of teaching. San Francisco: Jossey-Bass.

Majidi, M. (Dir.), 1999. The colour of paradise. DVD. Iran: Varahonar Company.

McLaren, P. 2009. Critical pedagogy: a look at the major concepts. In Darder, A., Baltodano, M.P. and Torres, R.D. (Eds), The critical pedagogy reader. New York: Routledge, pp.61-83. 
Mda, Z. 2002. The Madonna of Excelsior. Cape Town: Oxford University Press.

Morrow, R.A., and Torres, C.A. 1995. Social theory and education: a critique of theories of social and cultural reproduction. New York: SUNY Press.

Moser, H. 1975. Aktionsforschung als kritische Theorie der Sozialwissenschaften. München, Kösel.

Park, P. 1993. What is participatory research? A theoretical and methodological perspective. In Park, P., Brydon-Miller, M., Hall, B. and Jackson, T. (Eds), Voices of change: participatory research in the United States and Canada. Toronto: Ontario Institute for Studies in Education, pp.1-19.

Priestley, M., Edwards, R., Priestley, A. and Miller, K. 2012. Teacher agency in curriculum making: agents of change and spaces to manoeuvre. Curriculum Inquiry, 42(2): pp.191-214.

Reason, P. and Bradbury, H. 2006. Handbook of action research: participative inquiry and practice. Thousand Oaks: Sage.

Roy, A. 1997. The God of small things. London: Flamingo.

Shakespeare, W. 1623. The Tempest. Cape Town: Juta and Company.

Swantz, M.L. 2008. Participatory action research as practice. In Reason, P. and Bradbury, H. (Eds), Sage Handbook of Action Research. Thousand Oaks: Sage, pp.31-45.

The Junction Avenue Theatre Company. 1988. Sophiatown. Johannesburg: David Philip Publishers.

Torbert, W.B. 2004. Action inquiry: the secret of timely and transforming leadership. SF: Berrett-Koehler.

Van der Meulen, E. 2011. Participatory and action-oriented dissertations: the challenges and importance of community-engaged graduate research. The Qualitative Report, 16(5): pp.1291-1303. 
Waters-Adams, S. 2006. Action research in education. Faculty of Education, University of Plymouth. Available:

http://www.edu.plymouth.ac.uk/resined/actionresearch/arhome.htm [Accessed 10 June 2013.

Whitehead, J. and McNiff, J. 2009. Doing and writing action research. London: Sage.

Ansurie Pillay

School of Education

University of KwaZulu-Natal

pillaya3@ukzn.ac.za 